\title{
Pendidikan Karakter Dalam Cerita Rakyat Genuk Kemiri
}

\author{
Uswatun Khasanah*, Irfai Fathurohman, Deka Setiawan \\ Universitas Muria Kudus, Indonesia \\ *Coresponding Author: 201633224@std.umk.ac.id
}

Article History:

Received 2021-10-28

Revised 2022-01-05

Accepted 2022-01-22

DOI:

10.31949/educatio.v8i1.1611

\begin{abstract}
Character education is one of the important pillars that play a role in the implementation of education. Character education in schools can be pursued in many ways, one of which is the media of literary works. This study aims to describe the values of character education contained in the folklore of Genuk Kemiri, Pati Regency. This study uses a qualitative approach and descriptive data analysis. The place of this research was carried out at SDN Sarirejo 01, Sarirejo Village, Pati District, Pati Regency. Sources of data in this study were fourth grade teachers at SDN Sarirejo 01, caretakers for Genuk Kemiri, students at SDN Sarirejo 01, and parents of students. Data obtained through observation, interviews, and documentation. The data analysis used includes data reduction, data presentation, and conclusion drawing and verification. The results showed that in the folklore of Genuk Kemiri there was character education, including mutual cooperation and honesty. These character values indicate that folklore is not only used as a medium to introduce stories that are believed to be passed down from generation to generation, but also can be used as a means of educating students' character.
\end{abstract}

Keywords: character education; folklore

\section{PENDAHULUAN}

Karakter yang dimiliki oleh seseorang menjadi salah satu ciri khas yang membedakan satu individu dengan individu yang lainnya. Dalam hal ini, pembentukan karakter yang baik harus dilakukan sejak dini. Membentuk karakter bukanlah pekerjaan yang instan akan tetapi membutuhkan proses yang lama. Hal tersebut dapat dilakukan dengan melakukan pembiasaan melalui kegiatan yang baik, dimana kegiatan tersebut mengarah pada aturan sesuai dengan norma yang berlaku. Pendidikan karakter merupakan salah satu pilar penting yang turut berperan dalam penyelenggaraan pendidikan (Setyawan \& Suwandi, 2017). Akan tetapi, yang menjadi masalah saat ini di sekolah hanya berorientasi pada pengembangan pengetahuan sehingga kurang memperhatikan pengembangan keterampilan dan sikap. Pembentukan karakter merupakan salah satu 
aspek penting dari tujuan pendidikan. Pemerintah mencanangkan pendidikan karakter agar Indonesia memiliki sumber daya manusia tidak hanya unggul tetapi juga berkarakter. Karakter adalah bentuk watak, tabiat, akhlak yang melekat pada diri pribadi seseorang yang terbentuk dari hasil internalisasi yang digunakan sebagai landasan untuk berpikir dan berperilaku sehingga menimbulkan suatu ciri khas pada individu (Eku, 2019; Ismail \& Hadiana, 2014; Setiawan, 2014). Melalui pendidikan karakter dapat memilah budaya bangsa sendiri dan menyaring budaya bangsa lain yang tidak sesuai dengan nilai-nilai budaya bangsa dan karakter bangsa yang bermartabat (Zubaidi, 2011).

Lima nilai karakter utama yang saling berkaitan membentuk gerakan PPK (Penguatan Pendidikan Karakter). Nilai utama karakter bangsa sebagaimana yang dimaksud pada Permendikbud Nomor 20 Tahun 2018 pasal 2 yaitu (1) Religius. Yang dimaksud disini religius adalah merupakan perilaku dan sikap yang patuh dalam melaksanakan ajaran agama yang dianutnya dan menjauhi larangannya. Pendidikan karakter religius dilaksanakan di lingkungan rumah dan lingkungan sekolah. (2) Nasionalisme. Yang dimaksud disini nasionalisme adalah rasa cinta tanah air yang ada pada diri manusia. (3) Mandiri. Yang dimaksud disini mandiri adalah sikap dan perilaku yang tidak bergantung pada orang lain untuk menyelesaikan tugasnya. (4) Gotong royong. Yang dimaksud gotong royong disini adalah kegiatan yang dilakukan secara bersama-sama untuk memecahkan suatu masalah. (5) Integritas. Yang dimaksud disini integritas adalah segala upaya yang dilakukan untuk menjadikan dirinya dipercaya dalam hal perkataan, pekerjaan, tindakan dan komitmen.

Terkait dengan pelaksanaan pendidikan karakter di sekolah, pada dasarnya dapat ditempuh melalui banyak cara dan banyak media perantara. Salah satu di antaranya adalah dengan media karya sastra. Setiap karya sastra mengandung muatan-muatan pesan di dalamnya (Hasanah, 2015; Ngatman \& Fatimah, 2019). Muatan tersebut dapat meliputi muatan kebudayaan, kehidupan sosial, pendidikan, politik, keagamaan, lingkungan hidup, dan aspek-aspek lain dalam kehidupan. Melalui unsur imajinasinya, sastra mampu membimbing anak didik pada keluasan berpikir, bertindak, berkarya, dan sebagainya. Pengajaran sastra ini dipandang memiliki pertalian erat dengan internalisasi pendidikan karakter (Wibowo, 2013).

Indonesia memiliki keanekaragaman budaya dan sastra peninggalan nenek moyang yang tersebar di berbagai daerah. Seperti yang telah diketahui hasil sastra dibagi menjadi dua yaitu karya sastra berbentuk lisan dan karya sastra berbentuk tulisan. Karya sastra lisan banyak ditemukan pada masyarakat tradisional. Masyarakat tradisional merupakan masyarakat yang masih memegang unsur-unsur budaya yang diwariskan secara turun temurun seperti legenda, dongeng, mitologi, tahayul, mantera, drama tradisional dan unsur-unsur budaya contohnya upacara-upacara adat. Sastra lisan mengandung ajaran-ajaran luhur yang patut diwariskan, menyimpan informasi berharga berhubungan dengan asal-asul tempat atau benda yang dikeramatkan, agama, kepercayaan serta adat istiadat atau kebiasaan suatu daerah. Salah satu sastra lisan yang saat ini masih eksis di dalam dunia pendidikan adalah cerita rakyat. Cerita rakyat juga merupakan salah satu jenis karya sastra di samping puisi dan prosa yang lebih populer di masyarakat. Cerita rakyat adalah cerita pada masa lampau yang menjadi ciri khas setiap bangsa yang memiliki kultur budaya yang beraneka ragam mencakup kekayaan budaya dan sejarah yang dimiliki masing- masing bangsa (Sutopo \& Mustofa. 2015). Menurut Daulay (2014) cerita rakyat adalah budaya yang telah melekat pada kelompok masyarakat. Oleh karena itu, alur cerita, bahasa, tradisi, dan budaya yang ada dalam cerita kerap memiliki kedekatan dengan pemiliknya atau bahkan berupa cerminannya.

Cerita rakyat biasanya dapat dijadikan media untuk pembentukan nilai karakter yang harus dimiliki oleh siswa karena pada cerita rakyat terdapat amanat yang dapat diambil sebagai pembelajaran agar dapat diterapkan dalam diri siswa. Di samping sebagai media pembelajaran cerita rakyat dianggap sebagai kepercayaan yang mentradisi dalam masyarakat, dipertahankan oleh masyarakat pemiliknya dan salah satu bagian dari folklor. Cerita rakyat lebih dikenal masyarakat sebagai dongeng, legenda atau cerita lisan berlatar belakang sejarah. Sebagai sastra lisan, dalam cerita rakyat terkandung berbagai nilai norma, pendidikan, perjuangan, moral, kepahlawanan, dan pengabdian yang dapat dianut oleh masyarakat pada zaman sekarang. Cerita rakyat sebagai salah satu karya sastra yang lahir dan berkembang di lingkungan pemiliknya diyakini memiliki nilai-nilai kearifan lokal dan keluhuran budi/karakter dari pemilik cerita tersebut. Hal ini dapat dibuktikan dengan telah banyaknya peneliti yang mencoba menggali dan menelaah cerita rakyat untuk 
menemukan kandungan atau muatan-muatan di dalamnya, seperti penelitian Junaini et al (2017), Karmini (2020), Indiarti (2017), dan Ahmadi et al (2021).

Penelitian ini difokuskan pada pengkajian cerita rakyat Genuk Kemiri yang menjadi kekayaan sastra di Kabupaten Pati. Nilai-nilai pendidikan karakter yang dikaji yaitu berbagai nilai kepribadian luhur yang dapat diamati dari sikap dan tindakan tokoh dalam menghadapi berbagai macam pesoalan ataupun permasalahan dalam kehidupannya. Berdasarkan kondisi yang tejadi dan uraian di atas, maka penelitian ini bertujuan untuk mendeskripsikan pendidikan karakter yang terjandung dalam cerita rakyat Genuk Kemiri bagi siswa SDN Sarirejo 01 Pati.

\section{METODE PENELITIAN}

Metode penelitian yang digunakan dalam penelitian ini adalah pendekatan kualitatif dan analisis data secara deskriptif. Penelitian ini dilaksanakan pada tanggal 1-11 Maret 2021 di SDN Sarirejo 01, Kecamatan Pati Kabupaten Pati dan dalam prosesnya penelitian ini akan memperdalam pendidikan karakter yang terdapat dalam cerita rakyat Genuk Kemiri Kabupaten Pati di SDN Sarirejo 01.

Sumber data yang diambil yaitu sumber data primer dan sumber data sekunder. Sumber data primer yaitu sumber data yang diperoleh dari observasi dan wawancara yang didapatkan dari informan yaitu siswa SDN Sarirejo 01, guru kelas IV SDN Sarirejo 01, juru kunci Genuk Kemiri, dan orang tua siswa. Sumber data sekunder yaitu sumber data yang diperoleh dari dokumentasi, catatan penelitian dan data pendukung lainnya yang digunakan untuk pendukung penelitian. Sedangkan teknik pengumpulan data dalam penelitian ini dilakukan dengan metode observasi, wawancara, dan dokumentasi. Teknik analisis data yang digunakan dalam penelitian ini meliputi reduksi data, penyajian data dan langkah terakhir adalah penarikan kesimpulan dan verifikasi.

\section{HASIL DAN PEMBAHASAN}

Karakter merupakan cara berpikir dan berperilaku yang khas setiap individu untuk hidup dan bekerja sama dalam lingkungan keluarga, masyarakat, bangsa dan negara. Oleh karena itu nilai karakter merupakan salah satu upaya terencana untuk mentransformasikan, menanamkan dan membentuk manusia agar memiliki nilai religius, nasionalisme, mandiri, gotong royong dan integritas (Permendikbud Nomor 20 Tahun 2018 tentang gerakan PPK) sehingga akan menjadi manusia yang merdeka. Individu yang memiliki karakter yang baik adalah individu yang dapat membuat keputusan dan siap bertanggung jawab setiap akibat dari keputusannya. Samani (2014: 41) karakter dapat dianggap sebagai nilai-nilai perilaku manusia yang berhubungan dengan Tuhan Yang Maha Esa, sesama manusia, diri sendiri, lingkungan dan kebangsaan yang terwujud dalam pikiran, perasaan, perkataan, sikap, dan perbuatan berdasarkan norma hukum, agama, tata krama, budaya, estetika dan adat istiadat.

Salah satu aktualisasi nilai-nilai pendidikan karakter dapat ditunjukkan dengan adanya cerita rakyat. Cerita rakyat mengandung nilai-nilai karakter dalam masyarakat kebudayaan yang ada berhubungan dengan berbagai budaya, tingkah laku, sosial, dan cara berkomunikasi masyarakat. Salah satu unsur yang membangun cerita rakyat karena karakter yang muncul dalam suatu cerita baik karakter positif maupun negatif. Melalui tokoh dalam cerita yang menceritakan kehidupan memberikan nilai-nilai kebaikan, kejujuran, perjuangan, kesabaran, kesetiaan, dan sejenisnya yang dapat digunakan sebagai media dalam membentuk karakter positif pada siswa, disampaikan melalui jalan cerita sehingga prosesnya menyenangkan dan tidak menggurui.

a. Gotong Royong

Kegiatan gotong royong memiliki banyak nilai yang tekandung. Nilai-nilai dalam gotong royong mengarah pada kebersamaan masyarakat dalam melaksanakan peran dan tugasnya. Selain itu gotong royong memberikan nilai kebahagiaan dengan adanya tolong menolong dan kerja bakti antar masyarakat. Nilai karakter gotong royong yang terdapat dalam cerita rakyat Genuk Kemiri yaitu pada saat Raden Kembang Joyo dan pengikutnya melaksanakan babat alas. Gotong royong dilakukan agar pekerjaan menjadi lebih cepat 
selesai. Perilaku gotong royong harus tetap dilestarikan karena dalam kegiatan gotong royong memiliki nilainilai. Nilai-nilai tersebut antara lain saling kerja sama, saling menghargai, dan saling tolong menolong.

Cerita rakyat Genuk Kemiri dapat dijadikan materi pelajaran karena pada kelas IV karena terdapat materi pelajaran mengenai cerita rakyat. Sehingga cerita rakyat tersebut dapat dijadikan materi bacaan. Dalam kehidupan sehari-hari gotong royong dapat dilihat saat siswa melaksanakan piket kelas ada yang menyapu dan juga ada yang membersihkan papan tulis. Mereka melaksanakan tugasnya masing-masing tidak ada yang iri antara satu orang dengan orang lain. Adanya kegiatan seperti ini membuat mempererat hubungan antar siswa sehingga terjalin keakraban diantara mereka.

b. Kejujuran

Kejujuran merupakan karakter utama yang harus dimiliki oleh setiap individu. Kejujuran menjadi salah satu nilai moral yang mendasar sehingga menjadi panduan untuk seseorang dalam berperilaku. Perilaku jujur membuat seseorang menjadi lebih bertanggung jawab dan dapat menciptakan saling percaya antara satu dengan yang lain. Pada cerita rakyat Genuk Kemiri ada pesan moral yang dapat diambil siswa. Salah satunya yaitu kejujuran. Dapat dilihat pada saat Nyai Cekong tidak mau mengembalikan pusaka keris rambut pinutung yang dimiliki oleh Raden Kembang Joyo sehingga ia berubah menjadi genuk.. Kejujuran sangat dibutuhkan oleh siswa. Nilai kejujuran dapat dilihat saat siswa mengerjakan tugas. Siswa yang jujur akan mengerjakan tugas sendiri tanpa mencontek temannya. Dengan nilai kejujuran hidup akan lebih indah. Nilai kejujuran harus dimiliki oleh setiap manusia karena kejujuran merupakan cerminan dari diri seseorang.

Berdasarkan hasil penelitian ditemukan tiga nilai karakter luhur yang dapat diamati dari sikap dan perilaku yang ditunjukkan oleh tokoh-tokoh di dalamnya. Data-data temuan mengenai nilai pendidikan karakter dalam kumpulan cerita rakyat dari Pati tersebut menjadi bukti adanya warisan budaya dan keluhuran budi dari nenek moyang yang patut diteladani. Oleh karena itu, generasi muda sebagai generasi penerus bangsa berkewajiban menjaga dan melestarikannya. Selain itu, cerita rakyat yang sarat dengan nilainilai pendidikan karakter ini akan jauh lebih bermanfaat ketika digunakan sebagai bahan ajar dalam pembelajaran di sekolah-sekolah. Seperti disampaikan Sutopo dan Mustofa (2015) bahwa cerita rakyat sebagai salah satu jenis sastra tidak hanya mempunyai fungsi hiburan, tetapi yang paling penting di dalamnya terdapat hal-hal yang dapat digunakan sebagai media pendidikan, ko- munikasi, dan aktualisasi nilai-nilai luhur masyarakat pendukungnya. Dengan demikian dapat diartikan bahwa cerita rakyat juga dapat digunakan sebagai media untuk mengedukasi dan membentuk karakter dan kepribadian seseorang.

Indiarti (2017) dalam penelitiannya mengenai Cerita rakyat Banyuwangi yang berjudul Asal-usul Watu Dodol juga menemukan nilai-nilai pembentuk karakter bangsa di dalamnya. Dari temuan nilai-nilai pembentuk karakter yang diperoleh menunjukkan bahwa cerita rakyat tersebut mengandung cukup banyak nilai-nilai pembentuk karakter yang perlu dimiliki oleh setiap manusia agar dalam dirinya terbentuk sikap dan moral yang lebih baik. Oleh karena itu, nilai-nilai pembentuk karakter tersebut harus diterapkan oleh pendidik dan ditanamkan kepada siswa agar dapat diimplementasikan sesuai tugas dan perannya masingmasing, baik sebagai pendidik maupun peserta didik.

Berdasarkan data yang ditemukan dalam penelitian ini serta beberapa penelitian yang relevan dapat diketahui bahwa setiap daerah memiliki cerita rakyat masing-masing yang berbeda satu sama lain. Perbedaannya bukan sekadar terletak pada alur maupun unsur kebahasaannya saja, melainkan juga pada kandungan nilai-nilai karakter yang dimuat di dalamnya. Hal ini didasari oleh adanya perbedaan letak geografis, latar belakang budaya, serta adat tradisi yang dimiliki oleh masing-masing daerah. Nilai-nilai karakter yang ditemukan dalam penelitian ini dapat diartikan sebagai cerminan kepribadian mayarakat Pati. Berbagai nilai-nilai inilah yang kemudian dapat digunakan dalam dunia pendidikan sebagai sarana mendidik para generasi penerus bangsa. Melalui pembacaan cerita rakyat ini, siswa akan mengenal berbagai cerita rakyat di daerahnya sekaligus secara tidak sadar menggali nilai-nilai karakter luhur yang dikandungnya. Seperti diungkapkan Wibowo (2013) bahwa melalui penggalian yang lebih intens, karya sastra akan membuat anakanak lebih kaya, mengenal banyak karakter, mencintainya, dan mendorongnya untuk berbuat kebaikan. Apabila aktivitas ini dilakukan secara rutin, maka nilai-nilai ka- rakter yang berasal dari karya sastra, khususnya 
cerita rakyat ini akan mengkristal di dalam alam bawah sadar anak-anak. Nilai-nilai karakter yang mengkristal ini kemudian bisa menjadi kekuatan kepribadian dalam berperilaku sehari-hari.

\section{KESIMPULAN}

Nilai pendidikan karakter yang terkandung dalam Cerita Rakyat Genuk Kemiri Kabupaten Pati untuk anak-anak terutama SDN Sarirejo 01 antara lain gotong royong dan kejujuran. Sikap gotong royong royong harus dimiliki oleh siswa khususnya Sekolah Dasar. Nilai karakter gotong royong dapat diterapkan sehari-hari misalnya saat melaksanakan piket kelas sedangkan kejujuran contohnya pada saat mengerjakan tugas yang diberikan oleh guru.

\section{DAFTAR PUSTAKA}

Ahmadi, M., Ardianti, S. D., \& Pratiwi, I. A. (2021). Nilai Pendidikan Karakter Dalam Cerita Rakyat Sendang Widodari Kabupaten Kudus. Progres Pendidikan, 2(1), 1-6.

Daulay, I. R. (2014). Educative values in the lyric of onang-onang songs in the wedding ceremony of Batak Angkola, South Tapanuli Regency, Province of North Sumatra. Komposisi: Jurnal Pendidikan Bahasa, Sastra, dan Seni, 15(2), 148-165.

Eku, A. (2019). Kontekstualisasi Karakter Anak Melalui Pendidikan Dan Pembelajaran. Al-Wardab: Jurnal Kajian Perempuan, Gender dan Agama, 12(1), 20-32.

Hasanah, U. (2015). Sastra Modern Sebagai Media Pembelajaran Etika Moral Dan Karakter. Bahastra, 34(1).

Indiarti, W. (2017). Nilai-nilai pembentuk karakter dalam cerita rakyat asal-usul Watu Dodol. Jentera, 6(1), 2641.

Ismail, S., \& Hadiana, E. (2021). Kompetensi Guru Zaman Now Dalam Menghadapi Tantangan Di Era Revolusi Industri 4.0. At-Tajdid: Jurnal Pendidikan dan Pemikiran Islam, 4(02), 113-124.

Junaini, E., Agustina, E., \& Canrhas, A. (2017). Analisis nilai pendidikan karakter dalam cerita rakyat seluma. Jurnal Ilmiab KORPUS, 1(1), 39-43.

Karmini, N. N. (2020). Pendidikan Karakter Dalam Cerita Rakyat Rajapala. Mudra Jurnal Seni Budaya, 35(1), 22-29.

Ngatman, N., \& Fatimah, S. (2019). The Legend Of "Gunung Wurung" As Local Wisdom For Teaching Materials And Character Education In Elementary School. In Social, Humanities, and Educational Studies (SHEs): Conference Series , 1(2), 298-307.

Samani, M., \& Hariyanto. (2014). Konsep dan Model Pendidikan Karakter. Bandung: Remaja Rosdakarya.

Setiawan, A. (2014). Prinsip pendidikan karakter dalam islam: studi komparasi pemikiran al-Ghazali dan Burhanuddin al-Zarnuji. Dinamika Ilmu: Jumal Pendidikan, 14(1), 1-12.

Setyawan, A., \& Suwandi, S. (2017). Muatan pendidikan karakter dalam cerita rakyat di Pacitan. Jurnal Pendidikan Karakter, 7(2).

Sutopo, B. dan Mustofa, A. (2015). Kearifan Lokal dalam Cerita Rakyat Pacitan. Surakarta: Oase Pustaka.

Wibowo, A. (2013). Pendidikan Karakter Berbasis Sastra. Yogyakarta: Pustaka Pelajar.

Zubaidi. (2011). Desain Pendidikan Karakter Konsepsi dan Aplikasinya dalam Lembaga Pendidikan. Jakarta: Prenada Media Group. 